\title{
Carbon outwelling from a mangrove forest with adjacent seagrass beds and coral reefs (Gazi Bay, Kenya)
}

\author{
M. A. Hemminga ${ }^{1}$, F. J. Slim ${ }^{1}$, J. Kazungu ${ }^{2}$, G. M. Ganssen ${ }^{3}$, J. Nieuwenhuize ${ }^{1}$, \\ N. M. Kruyt ${ }^{4}$ \\ ${ }^{1}$ Netherlands Institute of Ecology, Centre for Estuarine and Coastal Ecology, Vierstraat 28, 4401 EA Yerseke, The Netherlands \\ ${ }^{2}$ Kenya Marine and Fisheries Research Institute, PO Box 81651, Mombasa, Kenya \\ ${ }^{3}$ Institute of Earth Sciences, Free University Amsterdam, De Boelelaan 1085, 1081 HV Amsterdam, The Netherlands \\ ${ }^{4}$ Institute for Marine and Atmospheric Research, Utrecht University, PO Box 80115, 3508 TC Utrecht, The Netherlands
}

\begin{abstract}
Carbon fluxes from a mangrove creek with adjacent seagrass meadows and coral reefs (at $4 \mathrm{~km}$ from the creek) were investigated in Gazi Bay (Kenya). Analysis of the stable isotope signature of sediment carbon in the seagrass zone and data on the sediment carbon content indicate that outwelling of particulate organic matter (POM) from the mangrove forest occurs, but that deposition of this POM rapidly decreases away from the forest. No evidence for any input of mangrove POM in the seagrass zone was found at a distance of $3 \mathrm{~km}$ from the mangrove creek, near the reefs. The gradient in sediment $\delta^{13} \mathrm{C}$ values in the seagrass zone was paralleled by a similar gradient of $\delta^{13} \mathrm{C}$ values in Thalassodendron ciliatum, the dominant subtidal seagrass. This gradient probably reflects the availability of respiratory $\mathrm{CO}_{2}$ derived from mangrove POM as a carbon source for the seagrass. Analysis of C:N ratios of particulate material $(<1 \mathrm{~mm})$ collected with sediment traps in the seagrass zone yielded values ranging from 8.5 to 11.2 . This range is remarkably low compared to $\mathrm{C}: \mathrm{N}$ ratios of plant material produced in the mangrove forest, and suggests that some of the mangrove-derived organic particles deposited in the seagrass zone have gone through a phase of intensive processing. During flood tides conspicuous decreases were found in $\delta^{13} \mathrm{C}$ values of seston flowing over the seagrass zone, coinciding with significant increases in the carbon content of the seston. These findings point to a reversed flux of organic particles from the seagrass zone to the mangrove forest. Our data indicate that, as far as POM fluxes are concerned, the mangrove forest and adjacent seagrass meadows are tightly coupled, but that the nearby coral reefs may exist in relative isolation.
\end{abstract}

KEY WORDS: Mangroves - Seagrass Coral reefs - Thalassodendron ciliatum - Stable carbon isotopes · Particulate organic matter - Outwelling

\section{INTRODUCTION}

Mangrove forests are open systems, coupled to coastal waters by tidal currents. Several studies indicate that export of particulate organic matter (POM) from mangrove forests may be a general feature of these systems (Boto \& Bunt 1981, Twilley 1985, Robertson 1986, Flores-Verdugo et al. 1987). The factors that determine the magnitude of this transport and the spreading of the material in the adjacent coastal zone are poorly known, but they include geomorphological and hydrodynamic factors (Twilley 1985, Woodroffe 1992, Wolanski et al. 1992). Mangroves occur in a number of different environmental settings. An intriguing situation is the co-occurrence of mangroves, seagrass meadows and coral reefs as adjacent systems in tropical coastal zones. It is known that the level of nutrient availability in both seagrass and reef systems may have profound effects on their structure and function (e.g. Harlin \& Thorne-Miller 1981, Smith et al. 1981, Brock \& Smith 1983, Short 1983, 1987, Birkeland 1987, Hallock 1988, Fourqurean et al. 1992). Thus, if 
particulate organic carbon and associated nutrients such as nitrogen and phosphorus are exported from the mangrove forest and enter the adjacent seagrass and reef systems, an influence on the structure and functioning of these systems is not unlikely. Although the potential chemical links between mangroves, seagrass beds and coral reefs have been suggested repeatedly, we are not aware of studies focusing on the actual existence of material fluxes among these 3 ecosystems. In the present study, we report on the fluxes of particulate carbon from a mangrove forest with adjacent seagrass beds and coral reefs in Gazi Bay (Kenya).

\section{METHODS}

Study area. Gazi Bay is situated $50 \mathrm{~km}$ south of Mombasa on the Kenyan coast $\left(4^{\circ} 25^{\prime} \mathrm{S}, 39^{\circ} 30^{\prime} \mathrm{E}\right)$. On the landward side a $6.61 \mathrm{~km}^{2}$ mangrove forest covers much of the bay (Fig. 1). There are 2 major tidal creeks penetrating the forest. The western creek is the mouth of the river Kidogoweni, a seasonal river. The eastern creek (Kinondo creek) is tidal; the present investigation focused on the outflow of this creek.

A total of 8 mangrove species are found in Gazi Bay. In the drainage area of Kinondo creek, the vegetation is dominated by Rhizophora mucronata, locally intermingled with Bruguiera gymnorrhiza and Ceriops tagal. Stands of Sonneratia alba and Avicennia marina are found along the creek fringes. Directly adjacent to the mangroves on the seaward side are intertidal flats intersected by channels, and shallow, subtidal areas. Both the intertidal and subtidal areas are to a large extent covered by various species of seagrass and, to a lesser extent, by macroalgae. Particularly relevant to this study was the subtidally growing seagrass Thalassodendron ciliatum. T. ciliatum forms dense beds in Kinondo creek and in the channels between the tidal flats. In subtidal areas of the bay, this seagrass is present in monospecific meadows which spread to the reef zone. $T$. ciliatum is a stem-forming species, giving the plant a total height of up to $80 \mathrm{~cm}$.

The reef zone in front of the bay is part of the fringing reef that forms a nearly uninterrupted belt along the Kenyan coast. The distance between the mouth of Kinondo creek and the reef zone is approximately $4 \mathrm{~km}$.

Tidal flow pattern. As part of the study of carbon fluxes, the tidal flow pattern of Kinondo creek and the adjacent seagrass zone was measured from 22 August to 25 September 1992 . Tidal heights were recorded by a pressure sensor, and were related to a stable reference point to yield relative values of tidal height. The circulation pattern for flood and ebb tides in this area was measured from a work platform near the mouth of the creek and a mobile dinghy. For each successive tidal cycle that was monitored, the dinghy was moved within the bay to positions chosen to represent the various morphological units of the study area. To measure the vertical velocity profile of the water column, strings of 5 propeller current meters (Ott) were used at the permanent station. At the dinghy, 3 current meters were used. Current directions were estimated from the bearings of the current meters. Current velocities were measured every $10 \mathrm{~min}$. Assuming that at the bottom the current velocity was zero, and that the velocity at the water surface was the same as that at the highest measured point in the vertical, the depth-averaged current velocity was calculated from the vertical velocity distribution as:

$$
\bar{U}=\frac{1}{h} \int_{0}^{h} U_{z} \mathrm{~d} z
$$

where $\bar{U}=$ mean current velocity over the water column depth $\left(\mathrm{cm} \mathrm{s}^{-1}\right) ; U_{z}=$ current velocity at $z \mathrm{~cm}$ above the bottom $\left(\mathrm{cm} \mathrm{s}^{-1}\right) ; h=$ water depth $(\mathrm{cm})$.

In order to construct the flow pattern in the bay on the basis of current velocities measured during different tidal cycles, it was necessary to transform the current velocities of each tide to the mean tidal situation. The average of all tidal ranges of the $848 \mathrm{~h}$ tidal data set was used for this transformation. Each tidal range was divided by the average value of this time series. By multiplying the resulting reduction coefficient with the mean current velocity, standardized current velocities were obtained.

Sampling. Sampling was carried out from 19 June to 7 July 1992. Various types of samples (see below) were taken on 4 subtidal transects, positioned in the channel forming the continuation of Kinondo creek and in the shallow bay waters closer to the reefs (Fig. 1). Thalassodendron ciliatum was the only, or the dominant, seagrass species on these transects. On each transect, 4 sediment cores were taken by scuba divers, using a sediment corer with an internal diameter of $7 \mathrm{~cm}$. The distance between sampling sites on a given transect was approximately $20 \mathrm{~m}$. The upper $7 \mathrm{~cm}$ of each core was immediateley transferred to a sample container. At each sampling site, the above-ground biomass of $T$. ciliatum was clipped from 3 plots of $25 \times 25 \mathrm{~cm}$. Sediment and seagrass samples were stored in cooling boxes until they were returned to the field laboratory where they were frozen $\left(-20^{\circ} \mathrm{C}\right)$ and lyophilized. The lyophilized sediments were sieved over a $2 \mathrm{~mm}$ mesh sieve to remove coarse material (mainly seagrass roots and mollusc shells). The 3 seagrass samples collected at each sampling site were pooled, yielding a total of 4 samples per transect. To decrease the variability which might arise from analyzing seagrass leaves of different developmental stage, only the third-youngest leaves of 
each $T$. ciliatum shoot in a sample were collected and used for further chemical analyses. These thirdyoungest leaves are nearly full-grown, but they lack the crust of epiphytes complicating the analysis of older leaves. Analyses were carried out after drying the leaf material at $70^{\circ} \mathrm{C}$.

Sediment traps were used to obtain particulate matter depositing in the seagrass zone. Four traps were positioned on each transect, in the plots which had been cleared of Thalassodendron ciliatum. The traps consisted of a PVC tube with an internal diameter of $7.6 \mathrm{~cm}$ and a length of $33 \mathrm{~cm}$, closed on one side by a PVC disc. A steel pin connected to the disc was used to anchor the tube in an upright position in the sediment. The opening of the traps was positioned at the level of the $T$. ciliatum canopy. After 10 to $17 \mathrm{~d}$ of deployment, the sediment traps were closed underwater with rubber stoppers and returned to the field laboratory. The

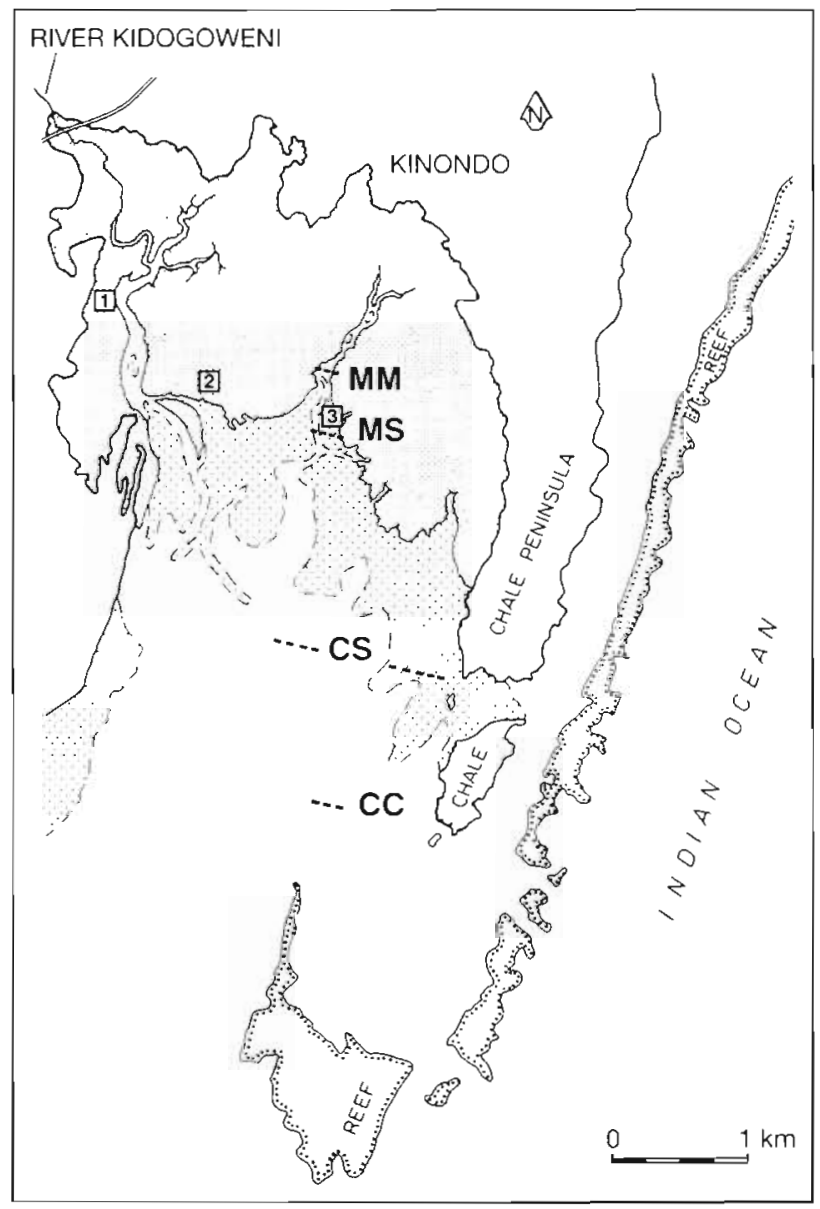

Fig. 1. Gazi Bay, Kenya. The mangrove area is indicated in dark grey. The seagrass zone is south of the mangrove forest; the intertidal part of it is indicated with light shading. Sampling transects in the seagrass zone are indicated with 2-letter codes. 1: Ceriops tagal sampling site; 2: Rhizophora mucronata sampling site; 3 : location of work platform contents were filtered through a $1 \mathrm{~mm}$ sieve, and the coarse matter retained on the filter was discarded. Subsequently, 200 to $400 \mathrm{ml}$ of the filtrate was filtered over Whatman GF/C filters. The particulate material retained on the filters was lyophilized prior to further chemical analyses.

To investigate changes in seston characteristics in the tidal water when it passed through the seagrass zone, seston samples were collected during 1 ebb tide (24 June) and 2 flood tides (30 June and 1 July). Ebb water flowing seaward from the mangrove forest was collected at the MM and CS transects. Incoming flood water was collected at the CC and MM transects. Water samples were collected over the full duration of each tide (approximately 1 sample $\mathrm{h}^{-1}$ at each transect). Water samples (25 l each) were collected with a hand diaphragm pump, $1 \mathrm{~m}$ above the subtidal sediment surface. The samples were immediately transported to the work platform near Kinondo creek, where 2.5 to 81 aliquots were filtered over Whatman $\mathrm{GF} / \mathrm{C}$ filters. The filters were stored in a cooling box for transport to the field laboratory and were dried by lyophilization.

Additional sediment samples (upper $7 \mathrm{~cm}$ ) were collected from the intertidal flats adjacent to the subtidal MS and CS transects, from stands of Rhizophora mucronata and Ceriops tagal, and from Chale lagoon, directly east of Gazi Bay (Fig. 1). This lagoon is separated from Gazi Bay by a broad sill of fossil coral that extends between Chale Peninsula and Chale Island, restricting direct water exchange between Gazi Bay and the lagoon. Thalassodendron ciliatum is abundant in the lagoon, and samples of this seagrass were also collected here. Processing of the sediment and seagrass samples was carried out as described above. Finally, green, fully grown leaves of all mangrove species present in Gazi Bay were collected and dried $\left(70^{\circ} \mathrm{C}\right)$ for chemical analyses.

Analyses. Carbon and nitrogen contents of sediment samples, sediment trap samples, seston and plant samples were determined with a Carlo Erba NA1500 CN analyzer. Except for the plant samples, all samples were pretreated with a solution of $25 \% \mathrm{HCl}$ to remove carbonates (for details see Nieuwenhuize et al. in press). To determine the carbonate content of sediment samples, aliquots of the dried and ground sediment were mixed with a solution of $25 \% \mathrm{HCl}$. The mixture was shaken mechanically. Evolved carbon dioxide was determined by volumetry.

Carbon isotope analyses were carried out on sediment samples, sediment trap samples, seston samples and on leaf samples of Thalassodendron ciliatum and the mangrove species. The samples were first introduced, if necessary after pretreatment with $25 \% \mathrm{HCl}$, into the CN analyzer (Carlo Erba NA1500). To purify 
the carbon dioxide generated by combustion of the samples in the element analyzer, the effluent gases were transferred to a system of condensation traps cooled with a mixture of solid carbon dioxide and ethanol, and with liquid nitrogen, to trap water and carbon dioxide respectively. The final collection tube with carbon dioxide from the sample was subsequently connected to a Finnigan MAT 251 mass spectrometer. Results are expressed as deviations in \% from the PDB standard, where

$$
\delta^{13} \mathrm{C}=\frac{\left({ }^{13} \mathrm{C} /{ }^{12} \mathrm{C}\right)_{\text {sample }}-\left({ }^{13} \mathrm{C} /{ }^{12} \mathrm{C}\right)_{\text {standard }}}{\left({ }^{13} \mathrm{C} /{ }^{12} \mathrm{C}\right)_{\text {standard }}} \times 1000
$$

The reproducibility of the isotope analysis was determuned with cane sugar ( $\mathrm{SD} \pm 0.14$, with $\mathrm{n}=14$, during the period of the measurements). Accuracy of the absolute values was determined using a certified char-

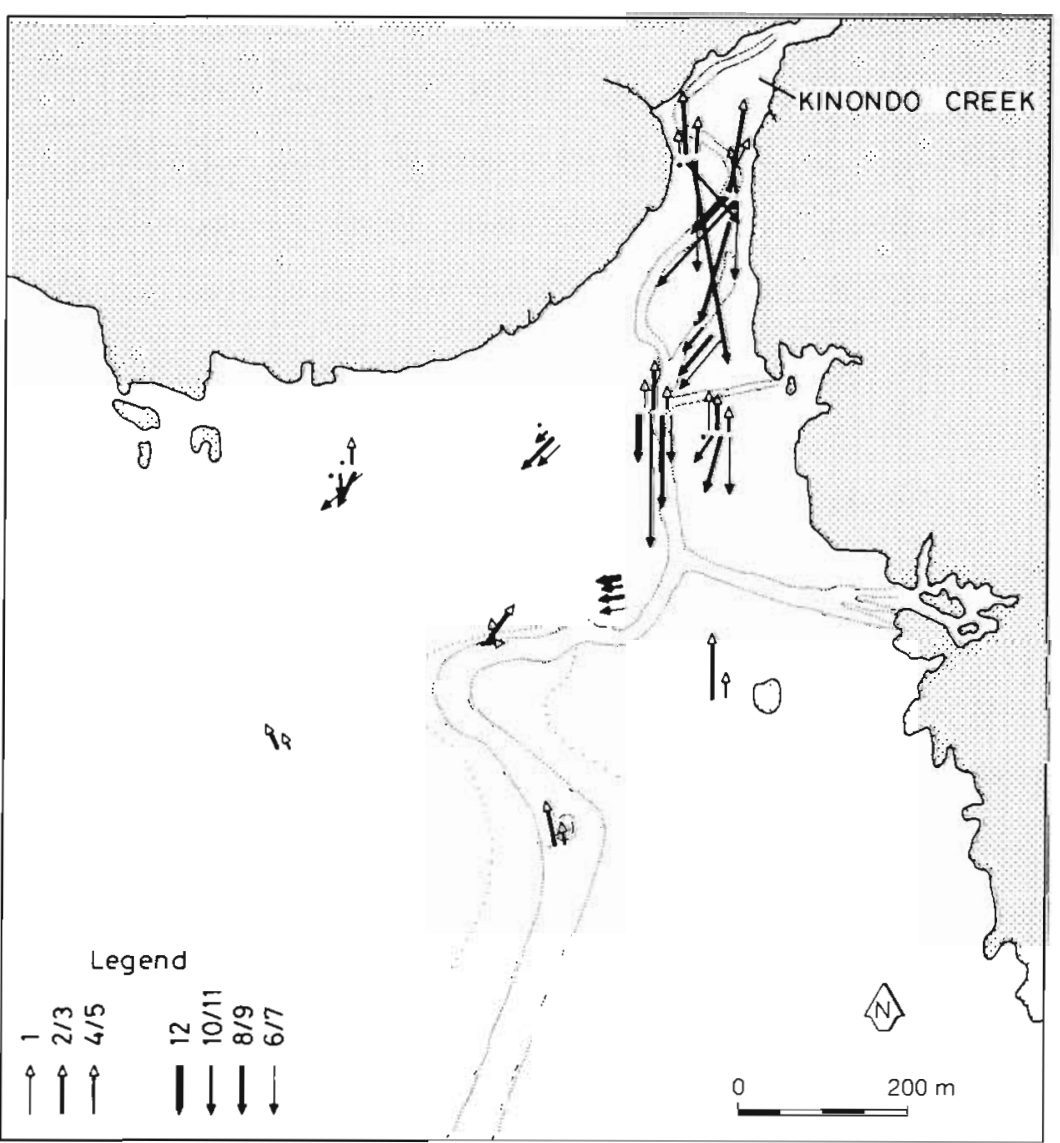

Fig 2. Circulation pattern for nsing and falling tide in the study area near Kunondo creek Arrows indicate flow direction Arrow length corresponds to the transformed current velocity. Different arrow styles indicate average flow charactenstıcs measured dunng the 1 st hour, 2 nd and 3 rd hour, and 4 th and 5 th hour of flood tide, and during the ebb tide, 1.e. dunng the 6 th and 7 th hour, 8 th and 9 th hour, 10th and 11th hour, and 12th hour after the beginning of the flood tide Points indicate current velocities below the detection limits of the flow meters coal standard $(-24.68 \%)$. Six measurements of this standard resulted in a mean value of $-24.62 \pm 0.11 \%$. The absolute difference between repeated determinations on the same homogenized field sample was usually less than $0.20 \%$.

Analysis of variance followed by post hoc contrasts was used for determining statistical differences in the various sets of results.

\section{RESULTS}

\section{Description of the tidal flow pattern}

Gazi Bay has a semi-diurnal tidal regime. The tidal amplitude measured during the $848 \mathrm{~h}$ monitoring period varied between $290 \mathrm{~cm}$ at spring tide and $70 \mathrm{~cm}$ at neap tide The flood period is usually shorter than the ebb period. At spring tide the flood tide lasts about 4 to $5 \mathrm{~h}$ and the subsequent ebb tide 7 to $8 \mathrm{~h}$. This inequality disappears towards neap tide. At neap tide flood and ebb are of equal duration. Fig. 2 shows the flow vectors at each of the measuring locations in the bay, mathematically transformed to represent the situation during an average tidal cycle. The tidal flow pattern in the bay can be derived from these data. In general, the current velocities at the entrance of Kinondo creek are much higher than in the bay. With rising tide, the incoming water first follows the channel leading to Kinondo creek. With increasing tidal height, the tidal flats are inundated and the water flows straight towards the mangrove forest. The mangrove forest is drained by the creek during the subsequent ebb tide. Water in the creek channel follows the channel until it enters the deeper parts of the bay. Water from the tidal flats crosses the flats into the bay until the final phase of the ebb tide. In this phase, water flows from the tidal flats towards the channel, which subsequently carries the water towards the deeper parts of the bay.

Fig. 3 shows that for the mean tidal range (i.e. data reduced to average tide) current velocities at the permanent station near the mouth of Kinondo creek are greater during ebb than during flood. The ebb current 


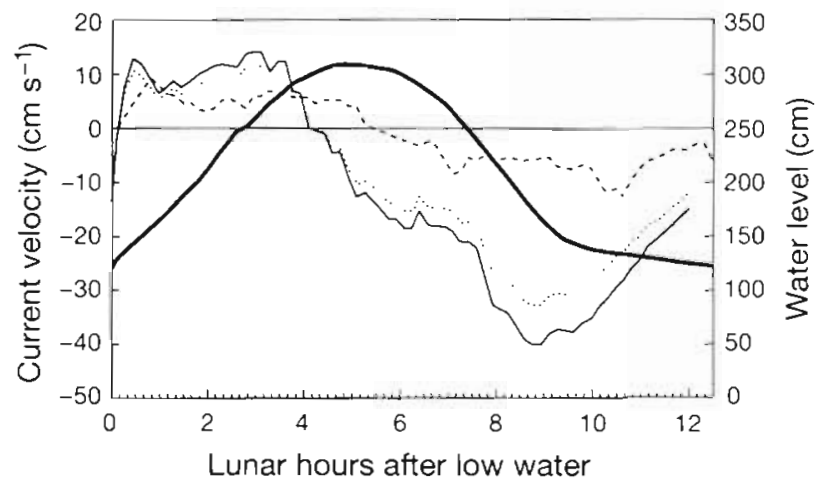

Fig. 3. Current velocities in the Kinondo creek channel near the work platform at spring tide (-), neap tide (-.-), and under average tidal conditions $(\cdots \cdots)$. The change in the water level over a tidal cycle is drawn for average tidal conditions ( - )

velocity is especially high at spring tide, up to $40 \mathrm{~cm}$ $\mathrm{s}^{-1}$. In agreement with these findings, discharge measurements (not shown) indicate that at ebb tide the volume of water efflux via Kinondo creek is 2 to 3 times higher than the incoming water volume at flood tide As no river influx is found in this part of the mangrove forest, this difference must be caused by a circulation of the water, once in the mangroves, towards the creek. Thus, Kinondo creek appears to function primarily as a tidal water export system.

\section{Outwelling of mangrove carbon}

Leaves form the major category of organic material produced by the mangrove trees in Gazi Bay (F. J. Slim unpubl. data). Table 1 shows the $\delta^{13} \mathrm{C}$ values of leaves of the various mangrove species occurring in Gazi Bay, ranging from $-28.25 \%$ for Rhizophora mucronata to $-24.12 \%$ for Ceriops tagal. $\delta^{13} \mathrm{C}$ values of organic matter in the sediments of $R$. mucronata and $C$. tagal
Table 1. Carbon isotope signature $\left(\delta^{13} \mathrm{C}\right)$ of mangrove leaves occurring in Gazi Bay. Means of 2 samples of pooled (10 to 20) leaves

\begin{tabular}{|ll|}
\hline Species & $\delta^{13} \mathrm{C}(\%)$ \\
\hline Rhizophora mucronata & -28.25 \\
Ceriops tagal & -24.12 \\
Sonneratia alba & -27.15 \\
Avicennia marina & -26.84 \\
Bruguiera gymnorrhiza & -27.30 \\
Xylocarpus granatum & -24.86 \\
Lumnitzera racemosa & -26.99 \\
Heritiera littoralis & -27.73 \\
\hline
\end{tabular}

stands ( -25.31 and $-22.69 \%$ respectively; see Table 2$)$ were less depleted than those of the leaves. The $\delta^{13} \mathrm{C}$ of sediment from Kinondo creek (MM transect) fell in the range of the mangrove sediments. However, as Table 2 shows, there was a conspicuous enrichment in ${ }^{13} \mathrm{C}$ in the seagrass zone away from the mangroves. At the $\mathrm{CC}$ transect the $\delta^{13} \mathrm{C}$ of the sediment $(-15.14 \%)$ was not significantly different from that of the sediment in Chale lagoon $(-14.75 \%)$, the sample location outside Gazi Bay. The data for the 2 intertidal locations show a similar trend.

The organic carbon content of sediment at the MM transect was relatively high. However, coinciding with the seaward enrichment in ${ }^{13} \mathrm{C}$, the organic carbon content of the subtidal sediments decreased significantly. These data suggest outwelling of mangrove-derived POM, but also suggest that this POM is trapped in the seagrass zone, close to the mangroves.

Enrichment in ${ }^{13} \mathrm{C}$ with increasing distance from the mangroves was also very clearly found in the Thalassodendron ciliatum growing at these sites (Table 3). Seagrass at any of the 4 subtidal transects, however, was always more enriched in ${ }^{13} \mathrm{C}$ than sediment at the same site.

Table 2. Carbon isotope signature $\left(\delta^{13} \mathrm{C}\right)$, and carbon and carbonate content ( $\%$ weight), of sediment samples in Gazi Bay and Chale lagoon. Means \pm SD shown. Data in a column sharing a common superscript letter are not significantly different $(\alpha=0.05)$

\begin{tabular}{|lcccc|}
\hline Location & $\delta^{13} \mathrm{C}(\%)$ & $\%$ Carbon & \% Carbonate & No. of obs. \\
\hline Mangrove Rhizophora mucronata & $-25.31 \pm 0.33^{\mathrm{a}}$ & $15.37 \pm 5.02$ & $1.20 \pm 0.66$ & 3 \\
Mangrove Ceriops tagal & $-22.69 \pm 0.57^{\mathrm{b}}$ & $1.71 \pm 0.24$ & $0.60 \pm 0.2$ & 3 \\
Subtidal, MM & $-22.94 \pm 0.26^{\mathrm{b}}$ & $3.78 \pm 0.95^{\mathrm{a}}$ & $38.77 \pm 4.86^{\mathrm{a}}$ & 4 \\
Subtidal, MS & $-20.61 \pm 1.46^{\mathrm{c}}$ & $2.22 \pm 0.88^{\mathrm{b}}$ & $43.30 \pm 6.11^{\mathrm{a}}$ & 4 \\
Subtidal, CS & $-18.48 \pm 0.31^{\mathrm{d}}$ & $0.68 \pm 0.16^{\mathrm{c}}$ & $27.65 \pm 7.85^{\mathrm{b}}$ & 4 \\
Subtidal, CC & $-15.14 \pm 0.77^{\mathrm{e}}$ & $0.67 \pm 0.45^{\mathrm{c}}$ & $80.30 \pm 2.01^{\mathrm{c}}$ & 4 \\
Chale lagoon & $-14.75 \pm 0.52^{\mathrm{e}}$ & $0.63 \pm 0.19^{\mathrm{c}}$ & $88.03 \pm 0.83^{\mathrm{c}}$ & 3 \\
Intertidal, MS & $-20.99 \pm 1.02^{\mathrm{c}}$ & $5.13 \pm 2.86$ & $55.42 \pm 5.87$ & \\
Intertidal, CS & $-17.13 \pm 0.76^{1}$ & $0.67 \pm 0.53$ & $59.70 \pm 33.30$ & 4 \\
\hline
\end{tabular}



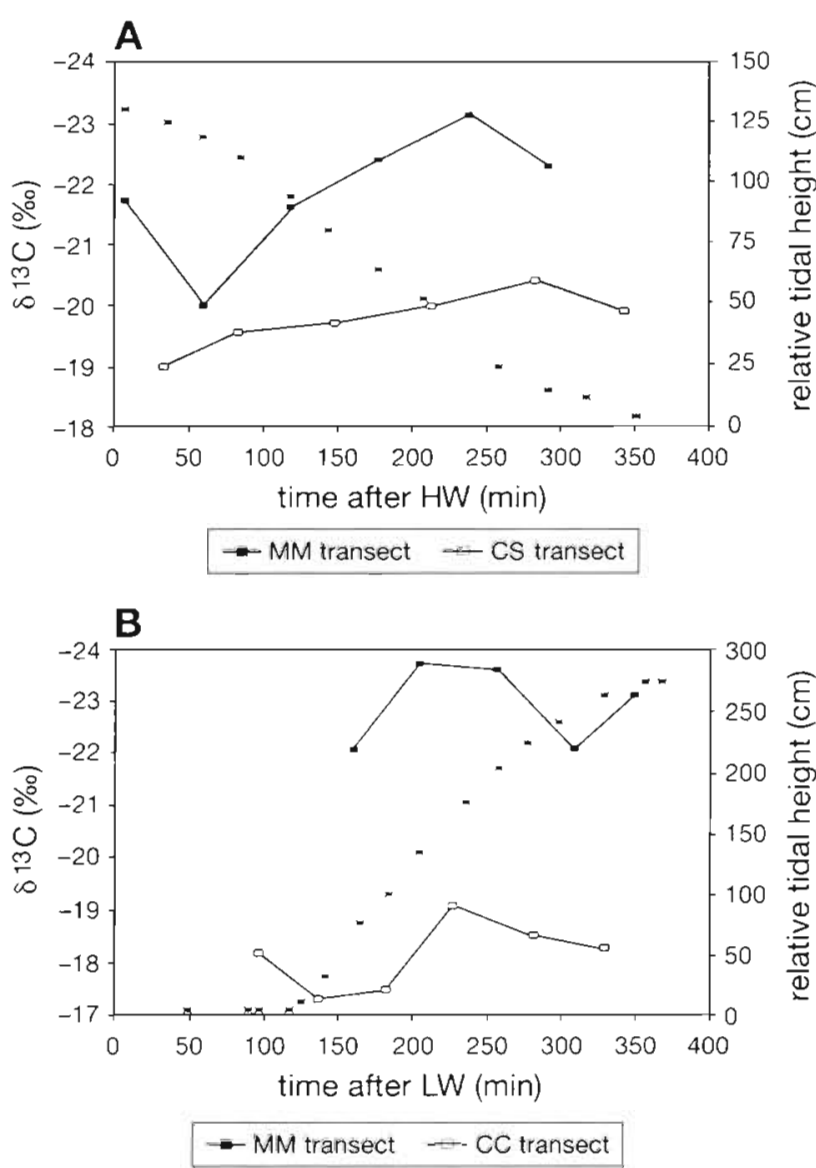

Fig. 4. Changes in $\delta^{13} \mathrm{C}$ values of seston in the tidal water of the seagrass zone, simultaneously collected at 2 transects over the duration of ebb or flood tide. - : results of tidal height measurements. (A) Ebb tide of 24 June 1992; (B) flood tide of 1 July 1992

\section{Organic matter fluxes from the seagrass zone}

$\delta^{13} \mathrm{C}$ values of seston. were determined to investigate whether shifts in organic composition of the seston occurred during the flow of the tidal water mass over the seagrass zone. Fig. $4 \mathrm{~A}$ shows results for ebb tide. At a distance of $2 \mathrm{~km}$ from the mangroves (at the CS transect), the seston was less depleted in ${ }^{13} \mathrm{C}$ than at the MM transect. The difference is statistically significant $(\mathrm{p}<0.01)$. No difference was found in salinity of the water between these locations. These results allow us to exclude the possibility that mixing of water ebbing from the eastern part of the mangroves with water from the river Kidogoweni caused the shift in carbon isotope signature. The increase in $\delta^{13} \mathrm{C}$ of the seston is consistent with the above-mentioned process of sedimentation of mangrove POM in the seagrass zone. However, uptake of particulate material from the seagrass zone could
Table 3. Carbon isotope signature $\left(\delta^{13} \mathrm{C}\right)$ of Thalassodendron ciliatum (third youngest leaves) growing at increasing distances from the mouth of Kinondo creek, Gazi Bay, and in Chale lagoon. Means \pm SD of 4 (pooled leaf) samples are shown. Data sharing a common superscript letter are not significantly different $(\alpha=0.05)$

\begin{tabular}{|lc|}
\hline Location & $\delta^{13} \mathrm{C}(\%)$ \\
\hline Subtidal, MM & $-19.65 \pm 0.39^{\mathrm{d}}$ \\
Subtidal, MS & $-18.30 \pm 0.45^{\mathrm{b}}$ \\
Subtidal, CS & $-15.77 \pm 0.47^{\mathrm{c}}$ \\
Subtidal, CC & $-10.70 \pm 0.23^{\mathrm{d}}$ \\
Chale lagoon & $-10.72 \pm 0.36^{\mathrm{d}}$ \\
\hline
\end{tabular}

Table 4. Seston and POC levels in tidal water crossing the seagrass zone. Means $\pm \mathrm{SD}$ of samples taken at approximately hourly intervals over the duration of the tide are shown. Differences between transect seston and POC data were statistically analyzed for each tide separately. Data sharing a common superscript letter are not significantly different $(\alpha=0.05)$

\begin{tabular}{|cccccc|}
\hline Tide & Date & Transect & $\begin{array}{c}\text { Seston } \\
\left(\mathrm{mg} \mathrm{l}^{-1}\right)\end{array}$ & $\begin{array}{c}\text { POC } \\
\left(\mathrm{mg} \mathrm{l}^{-1}\right)\end{array}$ & $\begin{array}{c}\text { No. of } \\
\text { obs. }\end{array}$ \\
\hline Ebb & 24 Jun & MM & $1.99 \pm 1.63^{\mathrm{a}}$ & $0.32 \pm 0.06^{\mathrm{a}}$ & 5 \\
& & $\mathrm{CS}$ & $3.30 \pm 1.53^{\mathrm{a}}$ & $0.46 \pm 0.16^{\mathrm{a}}$ & 5 \\
Flood & $30 \mathrm{Jun}$ & $\mathrm{CC}$ & $3.45 \pm 1.71^{\mathrm{a}}$ & $0.28 \pm 0.13^{\mathrm{a}}$ & 5 \\
& & $\mathrm{MM}$ & $6.23 \pm 2.56^{\mathrm{a}}$ & $1.12 \pm 0.39^{\mathrm{b}}$ & 5 \\
Flood & \multirow{2}{*}{ 1 Jul } & $\mathrm{CC}$ & $2.78 \pm 0.95^{\mathrm{a}}$ & $0.35 \pm 0.07^{\mathrm{a}}$ & 6 \\
& & $\mathrm{MM}$ & $8.65 \pm 6.61^{\mathrm{a}}$ & $1.76 \pm 1.27^{\mathrm{b}}$ & 5 \\
\hline
\end{tabular}

have contributed to the shift in $\delta^{13} \mathrm{C}$ values: there was a moderate increase in average seston and seston POC content going from the MM to the CS transect (Table 4), but the differences are not significant. Clearly, more data are needed before any conclusion can be made regarding this point.

Fig. $4 \mathrm{~B}$ shows seston $\delta^{13} \mathrm{C}$ data for the flood tide measurements of 1 July. The seston of ocean water entering the bay, sampled at the $\mathrm{CC}$ transect, had $\delta^{13} \mathrm{C}$ values between -17.27 and $-19.04 \%$ (mean $-18.10 \%$ ). However, when the water had crossed the seagrass zone and was about to enter the mangroves, the $\delta^{13} \mathrm{C}$ was consistently shifted to more negative values, ranging from -22.04 to $-23.70 \%$ (mean $-22.88 \%$ ). For the flood tide of 30 June (not shown) identical results were obtained (mean $\delta^{13} \mathrm{C}$ value at CC transect $-18.22 \%$; at MM transect $-23.43 \%$; means of 5 observations). These highly significant shifts $(p<0.001)$ were most probably due to resuspension and uptake of organic material in the seagrass zone, not to sedimentation processes: the ocean water that enters the bay has a relatively low POC content (CC transect, Table 4), but on reaching the $M M$ transect the $P O C$ content has increased significantly. Thus it appears that, besides 
Table 5. Carbon isotope signature $\left(\delta^{13} \mathrm{C}\right)$ of particulate organic material collected with sediment traps in the seagrass zone of Gazi Bay. Means \pm SD shown. Data sharing a common superscript letter are not significantly different $(\alpha=0.05)$

\begin{tabular}{|lcc|}
\hline Location & $\delta^{13} \mathrm{C}(\%)$ & No. of obs. \\
\hline Subtidal, MM & $-23.30 \pm 0.40^{\mathrm{a}}$ & 4 \\
Subtidal, MS & $-22.47 \pm 0.21^{\mathrm{a}}$ & 3 \\
Subtidal, CS & $-19.15 \pm 0.85^{\mathrm{b}}$ & 3 \\
Subtidal, CC & $-13.96 \pm 0.63^{\mathrm{c}}$ & 4 \\
\hline
\end{tabular}

outwelling of mangrove carbon, there is also a reversed transport of $\mathrm{POC}$ from the seagrass zone to the mangroves, driven by the incoming flood tides.

\section{Nature of material depositing in the seagrass zone}

Most of the sediment traps deployed in the seagrass zone contained some detached leaves or large leaf fragments of Thalassodendron ciliatum. This coarse material was not included in the chemical analyses of the trap contents, as the contents of the traps were filtered over a $1 \mathrm{~mm}$ sieve prior to analysis. The remaining material consisted of very fine, dark brown to black coloured, unrecognizable particles. $\delta^{13} \mathrm{C}$ values of this material increased from a strongly negative value of $-23.30 \%$ at the $\mathrm{MM}$ transect to $-13.96 \%$ at the $\mathrm{CC}$ transect (Table 5). C:N ratios of the material collected in the sediment traps (Table 6), varied between 8.5 and 11.2. $\mathrm{C}: \mathrm{N}$ ratios of seston filtered from the water were on average between 6.5 and 10 , and thus were of the same order of magnitude. There is a remarkable contrast between these values and the $\mathrm{C}: \mathrm{N}$ ratios of mangrove leaves, particularly senescent leaves, which can have C:N ratios of more than 200 .

\section{DISCUSSION}

The carbon isotope signatures of leaves and sediments collected in the mangrove forest show that the organic matter in the forest is characterized by strongly negative $\delta^{13} \mathrm{C}$ values. Only the $\delta^{13} \mathrm{C}$ value of the sediment in the seagrass zone close to the mangroves (MM transect) fell within the range of the mangrove sediment values. Further away, the mangrove signal faded out rapidly, and our data indicate that at a distance of only $2 \mathrm{~km}$ from the mouth of Kinondo creek the input of mangrove carbon was already of marginal influence in determining the $\delta^{13} \mathrm{C}$ value of the sediment. Thus it appears that during ebb flow, carbon depleted in ${ }^{13} \mathrm{C}$ is exported from the mangrove forest, but that all or part of this outwelling carbon is trapped in the seagrass zone before it reaches the coral reefs.

In principle, carbon outwelling from the mangroves may be tied up in both inorganic and organic molecules. Inorganic carbon-containing molecules (carbon dioxide, carbonate and bicarbonate), which are

Table 6. C:N ratios of sediment trap contents and of seston collected at subtidal transects during 1 ebb and 2 flood tides (data of the 2 flood tides were pooled). Statistical analyses of sediment trap and seston data were carried out separately. Data sharing a common superscript letter are not significantly different $(\alpha=0.05)$. For comparison, $\mathrm{C}$ : $\mathrm{N}$ ratios of the dominant seagrass and mangrove species in the study area are also given. The data on Thalassodendron ciliatum are from the 3 samples of pooled thirdyoungest leaves collected at the MM transect. Data on mangrove leaves are based on 2 samples of pooled leaves (10 to 20 leaves each). Means $\pm \mathrm{SD}$ shown. Number of observations given in parentheses

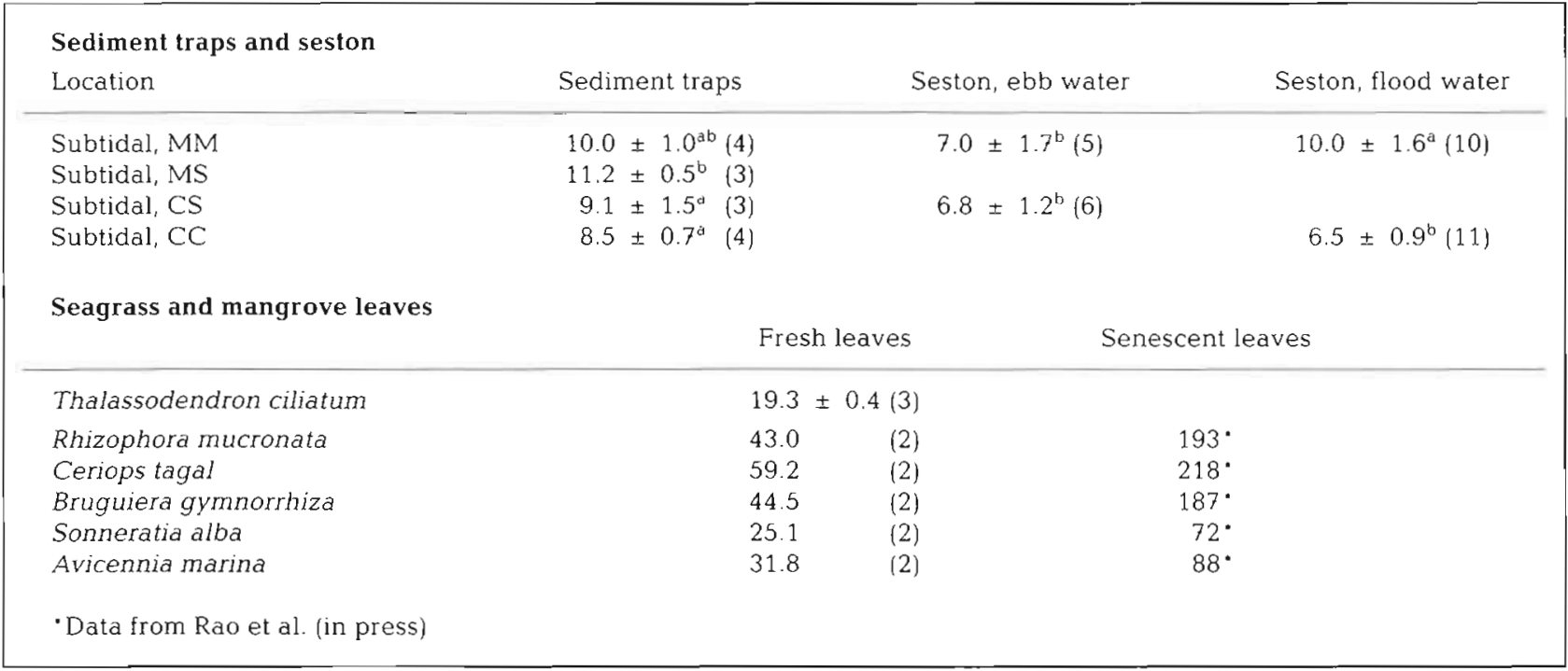


depleted in ${ }^{13} \mathrm{C}$, do occur in waters near mangroves. This can be inferred from the fact that marine molluscs, which depend on uptake of inorganic carbon from the seawater for the formation of shell carbonates, have shells with relatively low $\delta^{13} \mathrm{C}$ values in such environments (Lin et al. 1991). These authors assumed that inorganic carbon depleted in ${ }^{13} \mathrm{C}$ is generated by mineralization of mangrove detritus, deposited outside the mangrove area in nearshore waters. Although this certainly may be the case, we assume that ${ }^{13} \mathrm{C}$-depleted carbon dioxide may also enter the water during inundation of the mangrove forest. This inorganic carbon will be exported with the ebb flow, and, after assimilation, may contribute to the low ${ }^{13} \mathrm{C}$ values of the seagrasses in the proximity of the mangroves (see below).

Outwelling of ${ }^{13} \mathrm{C}$-depleted inorganic carbon from the mangrove forest is an interesting possibility that can be neither proven nor excluded on the basis of our data, and deserves further study. However, there is clearly evidence in our data that at least part of the ${ }^{13} \mathrm{C}$ depleted carbon exported from the mangroves of Gazi Bay leaves the system as POM which is subsequently trapped in the seagrass zone. The arguments for these processes are: (1) the decreasing organic content of the sediments in the seagrass zone with increasing distance from the mangroves, and (2) the conspicuously more ${ }^{13} \mathrm{C}$-depleted character of POC in the transect sediments compared to that of seagrass growing on the same sediments. This discrepancy would be unlikely if the sediment carbon isotope signature depended only on the input of seagrass material.

Remarkably, the carbon isotope signature of Thalassodendron ciliatum shows a trend similar to that of the sediment values with increasing distance from the mangroves. It is known that the isotope signature of seagrasses is highly variable (McMillan et al. 1980). Abel \& Drew (1989), in their review of carbon isotope discrimination in seagrasses, argued that the observed variability is consistent with the idea that the diffusion boundary layer around the leaves is a key factor in determining seagrass $\delta^{13} \mathrm{C}$ values. According to these authors, factors which increase the photosynthetic rate or the thickness of the boundary layer tend to increase the observed $\delta^{13} \mathrm{C}$ value. It is certainly conceivable that, in our study, differences in e.g. irradiance or current velocity contributed to the variability in $T$. ciliatum $\delta^{13} \mathrm{C}$ values. However, it is difficult to imagine that this environmental variability would result in a gradient which exactly parallels the input of mangrove carbon in the transect sediments. Low $\delta^{13} \mathrm{C}$ values of seagrasses growing in the proximity of mangrove forests have been reported before (Zieman et al. 1984, Fleming et al. 1990, Lin et al. 1991). More likely, the gradient in seagrass $\delta^{13} \mathrm{C}$ values in Gazi Bay reflects the amount of mangrove carbon that is available for assim- ilation by the seagrasses. $\mathrm{CO}_{2}$ resulting from the mineralization of mangrove POM trapped in the seagrass zone supplies $T$. ciliatum with inorganic carbon relatively depleted in ${ }^{13} \mathrm{C}$; and, as indicated above, the possibility cannot be excluded that dissolved respiratory $\mathrm{CO}_{2}$, directly exported from the mangrove forest, is a source of carbon for the seagrass.

There appears to be not only a simple unidirectional efflux of carbon from the mangroves, but also a reversed flux from the seagrass zone back to the mangroves. During both flood tides which were studied, highly significant decreases in the $\delta^{13} \mathrm{C}$ values of the seston from the $\mathrm{CC}$ to the $\mathrm{MM}$ transects were found (ca 5\%; Fig. 4B), coinciding with significant increases in the POC content of the seston. The $\delta^{13} \mathrm{C}$ values of the flood seston at the MM transect (ca $-23 \%$ ) are clearly more negative than that of the seagrass vegetation at this transect $(-19.65 \%)$. These strongly negative values suggest that at least part of the carbon taken up in the seagrass zone by the flood tides originally comes from the mangrove forest. Presumably, both autochthonous seagrass particles and allochthonous particles from the mangroves, deposited in the seagrass zone at earlier ebb tides, are taken up by the incoming water and transported into the forest. Moreover, circumstantial evidence for this process is found in the carbon isotope signature of the mangrove sediment. The sediment $\delta^{13} \mathrm{C}$ value of the Rhizophora mucronata sampling location, a low-lying site that is inundated each flood tide, is conspicuously less negative (by $2.9 \%$ ) than the $\delta^{13} \mathrm{C}$ values of the $R$. mucronata leaves. Such a decrease would not be expected if litter from the trees was the only source of organic matter in the sediment, especially since the carbon isotope signature of $R$. mucronata leaves in Gazi bay shows more pronounced ${ }^{13} \mathrm{C}$ depletion in senescent leaves prior to leaf fall (Rao et al. in press). Sedimentation of particulate material from the seagrass zone in the $R$. mucronata zone would result in less depleted sediment $\delta^{13} \mathrm{C}$ values. Using the $\delta^{13} \mathrm{C}$ values of the flood seston and those of the $R$. mucronata leaves as end members, a simple calculation indicates that to arrive at the sediment $\delta^{13} \mathrm{C}$ value, R. mucronata carbon and flood seston carbon would have to be mixed in a proportion of $1: 1.33$. At the Ceriops tagal site the difference between the carbon isotope signatures of sediment and leaf material was small (1.4\% lower in the sediment). This site is only inundated at spring tides, and the external input of tidally borne particulate matter probably is more restricted.

The material captured by the sediment traps in the seagrass zone was presumably a mixture of locally derived resuspended particles and allochthonous material. The shift in $\delta^{13} \mathrm{C}$ values moving seaward probably reflects the decreasing input of mangrove-derived par- 
ticles further away from the mangroves, and the contribution of local seagrass carbon. What is remarkable is the fact that the $\mathrm{C}: \mathrm{N}$ ratio of the seston collected in the sediment traps was low, varying between 8.5 and 11.2. Neither these values nor the $C: N$ ratios of the seston obtained by filtering the tidal water over the seagrass zone (ratios of 6.5 to 10 ) are close to the $C: N$ ratios of either mangroves or seagrasses (Table 6 ). Boto $\&$ Bunt (1981) studied POM transport from a mangrove creek in Missionary Bay (Australia), and found $\mathrm{C}: \mathrm{N}$ ratios between 8 and 200, depending on the tidal phase. There are at least 2 lines of explanation for the low $C: N$ ratios found in our study. First, the direct contribution of mangrove (and seagrass) detritus to the seston POM pool could be very low compared to that of other constituents with low $\mathrm{C}: \mathrm{N}$ ratios, such as phytoplankton, zooplankton and bacteria. However, if this is the case the gradient in sediment organic carbon content and in sediment $\delta^{13} \mathrm{C}$ values, moving from the mangroves toward the sea, and the strongly negative $\delta^{13} \mathrm{C}$ values of seston at the $\mathrm{MM}$ transect are difficult to explain. A more plausible explanation is that the seston contains an important fraction of organic particles derived from the mangroves and seagrass vegetation that has already gone through a phase of intensive processing, resulting in shifts in the chemical characteristics of these particles. We have suggested above that the organic particles from the mangroves (together with seagrass particles) may go through repeated efflux-reflux cycles. These transport cycles enhance the proportion of older, more processed organic material in the seston and may therefore be a crucial element in explaining the low $\mathrm{C}$ : $\mathrm{N}$ ratios of seston and seston trap material.

A progressive change in $\mathrm{C}: \mathrm{N}$ ratios may be caused by several processes. Increases in nitrogen levels during decomposition have been observed in many types of vascular plant detritus (Swift et al. 1979). Robertson (1988) also observed this phenomenon during decomposition in mangrove leaves. The $\mathrm{C}: \mathrm{N}$ ratio in decomposing leaves of Rhizophora stylosa, Avicennia marina and Ceriops tagal was approximately halved after $160 \mathrm{~d}$ of decomposition. This decrease in C:N ratios in decomposing plant litter may be due to the condensation of reactive phenolics and other compounds, released during decomposition, with microbial exudates (Rice 1982, Melillo et al. 1984, Rice \& Hanson 1984. Wilson et al. 1986a, b). Secondly, nitrogen fixation may enrich the litter. Nitrogen fixation activity is widespread in mangrove forests (Alongi et al. 1992), and is also found in association with decaying leaf litter (Goto \& Taylor 1976, van der Valk \& Attiwill 1984). The process has also been observed in tropical seagrass meadows, and may occur on plant detritus (Hemminga et al. 1991 and references therein). In agree- ment with these findings, nitrogen fixation has been found in both the mangroves and the Thalassodendron ciliatum meadows in Gazi Bay (A. F. Woitchik pers. comm.). Thirdly, several studies have shown that planktonic bacteria have a low carbon conversion efficiency on detrital substrates (Newell et al. 1981, Linley \& Newell 1984, Bauerfeind 1985, Bjørnsen 1986). We may speculate that a decrease in $C: N$ ratios of detritusbacteria aggregates is furthered by the low conversion efficiency of the heterotrophic bacteria associated with the particles.

The key features of POM fluxes in Gazi Bay which emerge from this study may be summarized as follows: (1) spatially restricted outwelling of mangrove carbon; (2) reversed fluxes of POM from the seagrass zone to the mangroves; (3) transported POM characterized by low $\mathrm{C}: \mathrm{N}$ ratios. These features may well be typical for mangrove forests with adjacent seagrass and fringing coral reef systems. The presence of the reef creates a low-energy environment on the landward side, restricting the hydrodynamic transport of particles. In addition, the seagrass vegetation will reduce dispersal of outwelling mangrove-derived particles: the presence of seagrasses enhances the sedimentation of particulate material from the overlying water column, as the resistance of the canopy causes a reduction in the current velocity of the water (Fonseca et al. 1982, Harlin et al. 1982, Ward et al. 1984). Furthermore, as coral reefs can only exist above salinities of $27 \%$, with optimal growth at salinities between 34 and $36 \%$ (Fagerstrom 1987 and references therein), the abundant occurrence of coral reefs in the proximity of mangroves is limited to tide-dominated (non-riverine) environments. According to Woodroffe (1992), tide-dominated mangrove habitats are characterized by bi-directional fluxes of suspended material, whereas river-dominated habitats are characterized by strong outwelling from the mangrove forest. Our data on the reversed flux of organic particles, from the seagrass zone to the tide-dominated mangrove system of Gazi Bay, fit into this scheme.

In Gazi Bay, and probably in other comparable coastal zones, the seagrass zone appears to function as a buffer between the mangroves and the coral reefs, trapping outwelling POM at close distance from the mangroves. This process reduces the input of mangrove-derived particles in the reef zone. Our data, however, provide no information on the transport of dissolved compounds and of floating macromaterial, such as leaves and twigs, from the mangrove forest to the coral reefs, nor can we exclude the possibility that a part of the mangrovederived POM may not undergo sedimentation at all and thus escapes to the coastal ocean.

The spatially restricted outwelling of mangrove POM implies that effects of the exported mangrove 
POM must be sought primarily in the adjacent seagrass zone. In addition, the flux of resuspended material from the seagrass zone to the mangroves may have an impact on the mangrove system. Limited data are available on the significance of outwelled mangrove detritus. Deposition of mangrove detritus may enhance oxygen consumption in offshore sediments (Alongi 1990), but decreases macro-infaunal densities and nematode species diversity (Alongi \& Christoffersen 1992). Supplements of mangrove litter in laboratory experiments did not affect bacterial densities or production in the sediment, or the growth of ciliate and flagellate populations (Alongi et al. 1989, Alongi 1990). Rodelli et al. (1984) determined the carbon isotope signature of a large number of organisms in a coastal area with mangroves. They found evidence that some animals from the mangroves and nearby mudflats and inlets derived a part of their nutrition from mangrove detritus, but that this was not the case for animals collected further offshore $(>2 \mathrm{~km})$. In these studies, the probably refractory character and poor nutritional quality of the outwelled material are frequently mentioned. The high C: $N$ ratio of mangrove detritus is considered relevant to these characteristics. Alongi \& Christoffersen (1992), for instance, established C:N ratios (w/w) ranging from 27 to 49 in mangrove detritus deposited at various offshore stations. The fine particulate material collected in the sediment traps in Gazi Bay, however, has a conspicuously lower $\mathrm{C}: \mathrm{N}$ ratio. The implications this may have for the functioning of the seagrass system remain to be investigated.

Acknowledgements. We gratefully acknowledge the indispensable contributions of international and national organizations to this study. The present research was carried out in the scientific framework of the project 'Interlinkages between Eastern-African ecosystems', which is funded by the Commission of the European Communities under the STD-3 programme (Contract No. TS3 ${ }^{\circ}$-CT92-0114). The fieldwork was carried out during the Netherlands Indian Ocean Expedition. The Netherlands Marine Research Foundation (SOZ) of the Netherlands Organization of Scientific Research (NWO) funded this expedition and provided the extensive logistical support required for this study. This is NIOO-CEMO publication no. 650

\section{LITERATURE CITED}

Abel, K. M., Drew, E. A. (1989). Carbon metabolism. In: Larkum, A. W. D., McComb. A. J., Shepherd, S. A. (eds.) Biology of seagrasses. Elsevier, Amsterdam, p. 760-796

Alongi, D. M. (1990). Abundances of benthic microfauna in relation to outwelling of mangrove detritus in a tropical coastal region. Mar. Ecol. Prog. Ser. 63: 53-63

Alongi, D. M., Boto, K. G., Robertson, A. I. (1992). Nitrogen and phosphorus cycles. In: Robertson, A. I., Alongi, D. M (eds.) Tropical mangrove ecosystems. American Geophysical Union, Washington, DC, p. 251-292
Alongi, D. M., Boto, K. G., Tirendi, F. (1989). Effect of exported mangrove litter on bacterial productivity and dissolved organic carbon fluxes in adjacent tropical nearshore sediments. Mar. Ecol. Prog. Ser. 56: 133-144

Alongi, D. M. Christoffersen, P. (1992). Benthic infauna and organism-sediment relations in a shallow, tropical area influence of outwelled mangrove detritus and physical disturbance. Mar. Ecol. Prog. Ser. 81: 229-245

Bauerfeind, S. (1985). Degradation of phytoplankton detritus by bacteria: estimation of bacterial consumption and respiration in an oxygen chamber. Mar. Ecol. Prog. Ser. 21: $27-36$

Birkeland, C. (1987). Nutrient availability as a major determinant of differences among hard-substratum communities in different regions of the tropics. In: Birkeland, C. (ed.) Differences between Atlantic and Pacific tropical marine coastal ecosystems: community structure, ecological processes, and productivity. UNESCO, Paris, p. 45-90

Bjornsen, P. K. (1986). Bacterioplankton growth yield in continuous seawater cultures. Mar. Ecol. Prog. Ser. 30: $191-196$

Boto, K. G., Bunt, J. S. (1981). Tidal export of particulate organic matter from a Northern Australian mangrove system. Estuar. coast. Shelf Sci. 13: 247-255

Brock, R. E., Smith, S. V. (1983). Response of coral reef cryptofaunal communities to food and space. Coral Reefs 1: 179-193

Fagerstrom, J. A. (1987). The evolution of reef communities John Wiley, New York

Fleming, M. Lin, G., da Silveria Lobo Sternberg, L. (1990). Influence of mangrove detritus in an estuarine ecosystem. Bull. mar. Sci. 47: 663-669

Flores-Verdugo, F. J., Day, J. W., Briseno-Duenas, R. (1987). Structure, litter fall, decomposition, and detritus dynamics of mangroves in a Mexican coastal lagoon with an ephemeral inlet. Mar. Ecol. Prog. Ser. 35: 83-90

Fonseca, M. S., Fisher, J. S., Zieman, J. C., Thayer, G. W. (1982). Influence of the seagrass, Zostera marina L., on current flow. Estuar. coast. Shelf Sci. 15: 351-364

Fourqurean, J W., Zieman, J. C., Powell, G. V. N. (1992). Relationships between porewater nutrients and seagrasses in a subtropical carbonate environment. Mar. Biol. 114: $57-65$

Goto, J W. Taylor, B. F. (1976). N $\mathrm{N}_{2}$ fixation associated with decaying leaves of the red mangrove (Rhizophora mangle). Appl. environ. Microbiol. 31:781-783

Hallock, P. (1988). The role of nutrient availability in bioerosion: consequences to carbonate buildups. Palaeogeogr. Palaeoclimatol. Palaeoecol. 63: 275-291

Harlin, M. M., Thorne-Miller, B. (1981). Nutrient enrichment of seagrass beds in a Rhode Island coastal lagoon. Mar. Biol. 65: 221-229

Harlin, M. M., Thorne-Miller, B., Boothroyd, J. C. (1982). Seagrass-sediment dynamics of a flood-tidal delta in Rhode lsland (U.S.A.). Aquat. Bot. 14: 127-138

Hemminga, M. A., Harrison, P. G., Van Lent, F. (1991). The balance of nutrient losses and gains in seagrass meadows. Mar. Ecol. Prog. Ser. 71. 85-96

Lin, G., Banks, T., da Silveria Lobo O'Reilly Sternberg, L. (1991). Variation in $\delta^{13} \mathrm{C}$ values for the seagrass Thalassia testudinum and its relations to mangrove carbon. Aquat. Bot. $40: 333-341$

Linley, E. A. S., Newell, R. C. (1984). Estimates of bacterial growth yields based on plant detritus. Bull. mar Sci. 35: $409-425$

McMillan, C., Parker, P. L, Fry, B. $(1980) .{ }^{13} \mathrm{C} /{ }^{12} \mathrm{C}$ ratios in seagrasses. Aquat. Bot. 9:237-249 
Melillo, J. M., Naiman, R. J., Aber, J. D., Linkins, A. E. (1984). Factors controlling mass loss and nitrogen dynamics of plant litter decaying in northern streams. Bull. mar. Sci. 35: $341-356$

Newell, R. C., Lucas, M. I., Linley, E. A. S. (1981). Rate of degradation and efficiency of conversion of phytoplankton debris by marine micro-organisms. Mar. Ecol. Prog. Ser. 6: $123-136$

Nieuwenhuize, J., Maas, Y E. M., Middelburg, J. (in press). Rapid analysis of organic carbon and nitrogen in particulate materials. Mar. Chem.

Rao, R. G., Woitchik, A. F., Goeyens, L., Van Riet, A., Kazungu, J., Dehairs, F. (in press). Carbon, nitrogen contents and stable carbon isotope abundance in mangrove leaves from an East African coastal lagoon (Kenya). Aquat. Bot.

Rice, D. L. (1982). The detritus nitrogen problem: new observations and perspectives from organic geochemistry. Mar. Ecol. Prog. Ser. 9: 153-162

Rice, D. L., Hanson, R. B. (1984). A kinetic model for detritus nitrogen: role of associated bacteria in nitrogen accumulation. Bull. mar, Sci. 35: 326-340

Robertson, A. I. (1986). Leaf-burying crabs: their influence on energy flow and export from mixed mangrove forests (Rhizophora spp.) in north east Australia. J. exp. mar. Biol. Ecol. 102: $237-248$

Robertson, A. I. (1988). Decomposition of mangrove leaf litter in tropical Australia. J. exp. mar. Biol. Ecol. 116: 235-247.

Rodelli, M. R., Gearing, J. N., Gearing, P. J., Marshall, N., Sasekumar, A. (1984). Stable isotope ratio as a tracer of mangrove carbon in Malaysian ecosystems. Oecologia 61: $326-333$

Short, F. T. (1983). The seagrass, Zostera marina L.: plant morphology and bed structure in relation to sediment ammonium in Izembek Lagoon, Alaska. Aquat. Bot. 16: 149-161

Short, F. T (1987). Effects of sediment nutrients on seagrasses: literature review and mesocosmos experiment.

This article was submitted to the editor
Aquat. Bot. 27: 41-57

Smith, S. V., Kimmerer, W. J., Laws, E. A., Brock, R. E., Walsh, T W. (1981). Kaneohe Bay sewage diversion experiment: perspectives on ecosystem responses to nutritional perturbation. Pacif. Sci. 35: 279-395

Swift, M. J., Heal, O. W., Anderson, J. M. (1979). Decomposition in terrestrial ecosystems. Blackwell, Oxford

Twilley, R. R. (1985). The exchange of organic carbon in basin mangrove forests in a southwest Florida estuary. Estuar coast. Shelf Sci. 20: 543-557

van der Valk, A., Attiwill, P. M. (1984). Acetylene reduction in an Avicennia marina community in southern Australia. Austr. J. Bot. 32: 157-164

Ward, L. G., Kemp, W. M., Boynton, W. R. (1984). The influence of waves and seagrass communities on suspended particulates in an estuarine embayment. Mar. Geol. 59: $85-103$

Wilson, J. O., Buchsbaum, R., Valiela, I., Swain, T. (1986a). Decomposition in salt marsh ecosystems: phenolic dynamics during decay of litter of Spartina alterniflora. Mar. Ecol. Prog. Ser. 29: 177-187

Wilson, J. O., Valiela, I., Swain, T. (1986b). Carbohydrate dynamics during decay of litter of Spartina alterniflora. Mar. Biol. 92: 277-284

Wolanski, E., Mazda, Y., Ridd, P. (1992). Mangrove hydrodynamics. In: Robertson, A. I., Alongi, D. M. (eds.) Tropical mangrove ecosystems. American Geophysical Union, Washington, DC, p. 43-62

Woodroffe, C. (1992). Mangrove sediments and geomorphology. In: Robertson, A. I., Alongi, D. M. (eds.) Tropical mangrove ecosystems. American Geophysical Union, Washington, DC, p. 7-42

Zieman, J. C., Macko, S. A., Mills, A. L. (1984). Role of seagrasses and mangroves in estuarine food webs: temporal and spatial changres in stable isotope composition and amino acid content during decomposition. Bull. mar. Sci. 35: $380-392$

Manuscript first received: November 11, 1993

Revised version accepted: January 24, 1994 